\title{
THE INTEGRATION OF NAQLI KNOWLEDGE OF SCIENCE COURSES IN INSTITUTIONS OF HIGHER LEARNING FOUNDATION CENTRES: STUDY ON TAMHIDI CENTRE, UNIVERSITI SAINS ISLAM MALAYSIA
}

\author{
Mohamed Akhiruddin Ibrahim \\ Dr, Senior Lecturer, Faculty of Quranic and Sunnah Studies \& Director of Tamhidi Centre, \\ Universiti Sains Islam Malaysia, MALAYSIA, akhiruddin@usim.edu.my
}

\begin{abstract}
Naqli knowledge refers to knowledge sourced from the Quran and sunah from the prophet p.u.h. since there are many verses from the Quran and hadiths which give insights to modern scientific field. This article discusses issues in relation to the different science disciplines such as physics and chemistry. In physics, many topics can be integrated with the use of Naqli in its teaching including physical quantities, kinematics, force, impulse and momentum, work, energy and power, statics, circular motion, kinematic of rotation of rigid bodies, gravitation, simple harmonic motion and oscillation, mechanical waves, deformation of solids and fluid mechanics. Whereas with regard to chemistry, the topics that could be integrated with Naqli knowledge includes matter, state of matter, atomic structure, periodic table, chemical bonding, chemical equilibrium, ionic equilibria and phase equilibrium. Some of the topics in this discipline are studied in its relation to the Quran. The methodology of this research focusses more on library studies, looking at courses in physics and chemistry at the Tamhidi Centre, Universiti Sains Islam Malaysia. Next, several topics were selected as sample. After seeing the title of general discussion a study on the verses of the Quran was made to see the link between the verse with the title that has been offered in the course. Selected paragraph submitted in English through the translation by Abdullah Yusuf Ali. From the findings, based on a number of titles that have been found in both these courses, it is found that there are many verses of the Quran that were linked either directly or indirectly with the title. It shows the title offered by Tamhidi through physics and chemistry courses, has direct link with particular Quran verses. To see the relationship between science and the Quran, it requires the knowledge and understanding of both the science.
\end{abstract}

Keywords: Naqli, sciences, Quran, curriculum, foundation.

\section{INTRODUCTION}

The integration of Naqli in courses based on Aqli knowledge is required to make a course that has its own strenght. This is because there is a noble effort to restore the concept of integration of knowledge in adult education curriculum is to restore the glory of Islamic civilization of the past. From another aspect, the knowledge derived from Naqli knowledge to the science of Aqli to show its relevance in accordance with current requirements, while science sourced Aqli knowledge also need the science Naqli for knowledge in order not to deviate from the ultimate truth. 


\section{MATRICULATION AND FOUNDATION STUDIES IN MALAYSIAN UNIVERSITIES}

For the higher education system in Malaysia, candidates are required to sit for at any institution at a certain level before enrolling as a student of first year degree level. At this stage, candidates who have completed the GCE O level or Sijil Pelajaran Malaysia will continue their studies at the foundation level or take the Sijil Tinggi Pelajaran Malaysia or Sijil Tinggi Agama Malaysia or diploma. In Malaysia, for fundamental studies there are two matriculation centres, which can be classified under foundation or matriculation centres under the auspices of any university. While the second basic type under the auspices of the Ministry of Education, better known as matriculation centres.

\subsection{Universities' Foundation Centres}

The admission process for the foundation centres of all public universities in Malaysia is operated by the Entry Management Division, Department of Higher Education, Ministry of Higher Education. This part is known as the Unit Pusat Universiti (UPU) in 1970 until October 10, 1995. After that date until December 31, 2004 it is known as the Student Intake Management Division of Higher Education Institutions (BPKP IPT). Starting January 1, 2005 until now, the name of this section has been shortened to the name Student Intake Management Division (BPKP) only (http://upu.mohe.gov.my/web/\#). This division is in charge of managing and coordinating the entry of students who have completed the Sijil Pelajaran Malaysia to enter any foundation centres of public universities nationwide. The Division provides specific codes (Ministry of Higher Education Malaysia, Student Entry Management Division) for each public university for applications for admission to the university. To date, there are 20 public universities in Malaysia which are managed by the division to manage the intake of students to the universities.

Apart from coordinating the admission of students to public universities, BPKP also monitor the balance of arts and science students so that there will not be a huge gap of quantity between the two fields. For this article, the focus is on the foundation centre in the Universiti Sains Islam Malaysia, which is designated as Tamhidi Centre which is the only public university in Malaysia which uses that specific name.

\subsection{Matriculation Centres under the Ministry of Education}

The matriculation centres have been established by the Ministry of Education on 1 September 1998. The main purpose of establishing of the matriculation centre is to standardise the basic programmes operated by public universities in Malaysia (Ministry of Education Malaysia, Matriculation Division). The matriculation centres are managed by the Ministry of Education, better known by the name Matriculation College. Up to now there are 17 matriculation colleges nationwide (Ministry of Education Malaysia, Matriculation Colleges). Fields of study offered at the centre include matriculation science, accounting and technical courses. Students pursuing studies in science will study courses in physics, chemistry, biology, mathematics and computer science. For students in the field of accounting, the students will study courses in accounting, mathematics, economics and business management. Whereas in the technical field, students must take courses of study in engineering, engineering physics, chemical engineering and mathematics. In addition to courses based in each field of study, students will also learn the English language, dynamic skills and Islamic studies or moral education. They are also required to take one course or curriculum that includes sports or games (Selangor Matriculation Centre). The duration of study in matriculation centre is for one year with two semesters, and those who graduate will qualify to pursuing a bachelor's degree in public universities and the private universities across the country. In the universities, the students will follow a programme of study in the areas of science such as medicine, dentistry, pharmacy, science, applied science, computer science, actuarial science, applied science, bio-medical, bio-physics, architecture, information technology and similar courses. While students in the field of accountancy, will have the opportunity to continue their studies at universities in accounting, business management, business administration, economics and similar courses.

\subsection{Tamhidi Centre, Universiti Sains Islam Malaysia}

The Tamhidi Centre, Universiti Sains Islam Malaysia is located in Bandar Baru Nilai, Negeri Sembilan, Malaysia about 30 kilometers from Putrajaya, the Federal Administrative Centre. It was founded in 2004 by starting its operations in PolyTech MARA College Building, Bangi. At the initial stage of operation, the centre used the science laboratory facilities at the National University of Malaysia. In that year, Tamhidi offers only one program only, Tamhidi of Medicine received a total of 29 students. Then the following year, 2005, two more programmes were offered namely Tamhidi of Science \& Technology and Tamhidi of Sharia \& Law. 
Subsequently in 2006, this centre has offered Tamhidi of Dentistry Programme and Tamhidi of Accounting \& Muamalat Programme (Sabri, 2015). Given that there have been five such programs, the centre has received so many applications from candidates with Sijil Pelajaran Malaysia to further their studies at the institution. The latest application, for academic session 2016/2017, the centre has received a total of 31,453 applications to study at this centre (Tamhidi Centre, 2016). From this total, only 1172 students were offered due to logistics capabilities of this center.

The main objective of the establishment of the Tamhidi Centre is to provide pre-university education opportunities, especially for students with Sijil Pelajaran Malaysia from religious schools (Aziz, et. Al., 2016). At the same time the existence of this centre can assist faculties in Universiti Sains Islam Malaysia to provide students a chance to study at degree level. From the curriculum offered, the courses offered at this centre show the integration of Aqli and Naqli. For courses that are based on Naqli knowledge such as the Quran, hadith and fikh, it is integrated with Aqli knowledge. While the courses based on Aqli knowledge such as physics, chemistry and biologyl, the centre provides an integrated course with knowledge of Naqli.

\section{SAMPLE OF THE INTEGRATION OF NAQLIIN PHYSICS}

\subsection{Physical Quantities}

The contents offered in the course of physics in Tamhidi Centre (Tamhidi Centre, Course Outline) discusses fundamental quantities and measurements. Measurement of fundamental quantities such as weight, as measured by the kilogram, length is measured using meter, time is measured by seconds, temperature is measured with a Kelvin and electric current measured by Ampere (Haynes, 2013). The base quantity may be issued as derived quantities such as density, velocity, momentum and power. In studying this topic, students should understand how to convert units. In studying this subject, students should understand how to convert units. An example of how the method for converting millimetre to centimetre, centimetre to metre and metre to kilometre. The title describes the physical quantities that quantities are divided into two types, namely the scalar and vector quantities (Verma, 2008). Scalar quantities only has magnitude (value) of mass, time, temperature and density. While vector quantity has both magnitude and direction such as velocity, acceleration and power.

In the Quran, this measurement concept was given priority as a guide to mankind. This view of measurement plays a very important in determining any action authorized or otherwise. If the measurement set is not followed, then it will produce a flawed life on this earth. Allah says in the Quran that means: "Give just measure and cause no loss (to others by fraud). And weigh with scales true and upright. And withhold not things justly due to men, nor do evil in the land, working mischief. And fear Him Who created you and (Who created) the generations before (you)" (Quran, 26:181-184). In addition, in a more general concept related to measurements in the universe, Allah says: "Verily, all things have We created in proportion and measure" (Quran, 54:49: It explains that everything was created by Allah on this earth has a certain rate or size. As another example, in terms of timing, the Quran has stressed the importance of time and people who do not take advantage of his time with useful things, including among the losers. The Holy Quran says "By (the Token of) time (through the Ages), Verily Man is in loss, Except such as have Faith, and do righteous deeds, and (join together) in the mutual teaching of Truth, and of Patience and Constancy" (Quran, 103:1-3). Similarly, the measurement of time, it cannot be hastened or delayed, even for a second. The Holy Quran says: "To every people is a term appointed: when their term is reached not an hour can they cause delay, nor (an hour) can they advance (it in anticipation)" (Quran, 7:34).

\subsection{Work, Energy and Power}

The title work, energy and power are also offered at the foundation level (Tamhidi Centre, Course Outline). Work is the body changes from a state to a state other when subjected to a force (Encyclopaedia Britannica). It also involves a change in the distance from the starting point to the end point. Energy also represents the ability of a body to do work. It exists in several forms such as mechanical energy, chemical energy, nuclear energy, kinetic energy, energy capability and so on (The Free High School Science Texts, 2005) While power is a body of work. Power can also be expressed as work done divided by the time taken (Kostic, 2004), (USNW, School of Physics). Time is very precious in life, the more work that can be done in a short time, the higher the value of the power.

In the Quran, it is stated that nuclear energy base is metal, which is very beneficial to the energy of human life. In science, there is an iron intermetallic compounds and other minerals which includes radioactive metal. For example, uranium, radium and plutonium. The power of this metal, which Allah says: "... and We sent 
down Iron, in which is (material for) mighty war, as well as many benefits for mankind..." (Quran, 57:25). In addition, there are a lot more energy and power that is revealed in the Quran. These include solar energy. The Holy Quran says: "Among His Signs are the Night and the Day and the sun and Moon..." (Quran, 41:37). In this verse clearly shows that Allah created the sun and the moon. With the sun, solar energy can help wildlife in nature is to continue the activities of life. This energy is endless and this energy is energy that is not contaminated as compared with other energy inherent in human creation. The effects of solar energy are very synonymous with the activities of human life in the universe. In the tropics fishing activities may be carried out throughout the year by the existence of the sun on a daily basis. Similarly, agricultural activities can be carried out during the year, which of course varies with countries in the Antarctic. The fact that one of the functions of solar energy, it is often mentioned in the Quran.

\subsection{Gravitation}

The next example of Naqli integration of science in physics courses at Tamhidi Centre is the title of gravity (Tamhidi Centre, Course Outline). Gravity is a force of attraction that acts between particles that have mass. Gravity determines the weight of an object from its mass (Glenn Research Centre, 2015). According to Isaac Newton, all mass in the universe pulls each other (Hyman, 1993). Newton says that gravity plays a role in ensuring that the moon and planets are in orbit. In the early 20th century, Albert Einstein had theorised the relative theory (Kox et. Al., 1997), which is said to compete with the theory put forward by Newton. This statement, is to prove that there are studies by scholars of gravity that exists in the universe. Gravity acts to maintain the position of the planet in its orbit (Cheshire, 2011). Without gravity, the earth can float in outer space, and beings such as humans and animals will be thrown out of this Earth.

Quran has signaled the existence of gravity in the universe, including the presence of gravity on the planet and the attraction is not there in space. Allah says: "Even if We opened out to them a gate from heaven, and they were to continue (all day) ascending therein, (14) They would only say:" Our eyes have been intoxicated: nay, we have been Bewitched by sorcery" (Quran, 15: 14-15). the purpose of this section is to show bewitched atmosphere when people can't control themselves, because there is no gravity in space. When there is no gravity, then the balance system of the human body can no longer function. The balance of the human body is based in the ear. There is a semicircular inside the human ear to accommodate liquid whose role is to balance the body (National Institute on Deafness and other Communication Disorders).

\section{SAMPLE OF THE INTERGRATION OF NAQLIIN CHEMISTRY}

\subsection{Thermochemistry}

Among the titles offered for courses in chemistry in Tamhidi is Thermochemistry (Tamhidi Centre, Course Outline). Thermochemistry is the study of heat change in chemical reactions (Abedin, et al, 2011). Chemicals have the bonds between atoms or molecules. These chemicals require energy to merge and split with each other. Heat changes exist when temperature is changed after the chemicals react. This chemical reaction is divided into two; the first reaction is Exotermic where the heat released into the environment out of the system, which resulted in high temperature. An example of these reactions is when a combustion reaction of combustible chemicals that react with oxygen. While the second reaction is endothermic named as the heat is absorbed into the material of the reaction, which causes the temperature of the reactants to increase (Abdul Maleque, 2013).An example of this reaction is like burning the bunsen burner, where the bunsen burner surface will feel cold and vapor droplets will be viewed.

In the Quran, there are many verses that touch aspects that have to do with chemistry. For example,the exhange of night and day with sunshine. Allah says: "He created the heavens and the earth in true (proportions): He makes the Night overlap the Day, and the Day overlap the Night: He has subjected the sun and the moon (to His law), each one follows a course for a time appointed ... "(Quran, 39: 5). This section describes the exchange of day and night and the moon in its orbit. In addition, it also involves the solar energy through solar which exists during the day. Chemical aspects can be seen as a form of solar energy in the ocean, air and plants (Ahmad, et. al., 2011). The daytime heating effect of sunlight causes the water molecules on the surface of the sea to form water vapour and then rises to the top. The water vapor evaporates and enters the cool atmosphere. In this case, water vapor is dampened again and then merges to form small beads, and consequently it becomes raindrops. 


\subsection{Reaction Kinetics}

Chemical kinetics title for chemistry courses are also offered in Tamhidi (Tamhidi Centre, Course Outline). Chemical kinetics also known as kinetics reaction is the study of chemical processes. Chemical kinetic includes the study of how different experimental conditions can affect the chemical reaction and producing information as well as the construction of a model that can describe the characteristics of the chemical reaction (Kazeroonian, et. al., 2016). A chemical reaction occurs when the reactants are mixed together in it. During a chemical reaction, the reactants are used until the formation of a product. There are several factors that affect the rate of reactions, of which the total surface area of the reaction, the greater the amount of surface area, the higher the response rate. In addition, the higher the concentrations of substance, the higher the response rate. Temperature also plays an important role in affecting the rate of reaction (Nermoen, et. al., 2016). The high temperature will affect the reaction rate; the high temperature will increase the particle kinetic energy of the reactants. In addition, high pressures also affect the rate of reaction.

If the observed rate of chemical reactions, it can be analogised to qisas punishment specified by the Quran. In the Quran (Quran, 2: 178, 5:45) response punishment for criminals guilty of hurting another person on purpose, then the government can sentence to hurt members of the same body part of the offender. Next, if the offender made a mistake by cutting others intentionally, if convicted, the offender can be punished by cutting the same body part by authority. For more severe cases, the offender committing the crime of killing intentionally, if the offender is convicted, an offense punishable by death could be imposed by the government. This analogy could be viewed from the aspect of factors that affect the chemical reactions those results in different response rates. Similarly, the law of qisas specified by the Quran, the reaction rate of the law, is highly dependent on the form of the offense committed by the offenders.

\subsection{Alcohol}

In Tamhidi's curriculum, the titles alcohol is listed in the chemical course and is listed in the syllabus (Tamhidi Centre, Course Outline). In the study of chemistry, alcohol is any organic compound in a hydroxyl group $(\mathrm{OH})$ attached to a carbon atom, and is also bound to a carbon atom of hydrogen or other (National Center for Biotechnology Information). Ethanol also is the main content of alcohol used to make alcoholic beverages. It uses yeast and sugar is produced through the fermentation process. Ethanol contained in drinks can lead to someone being sick and has loss of consciousness (Alcohol Advisory Council of New Zealand, 2012). In addition, ethanol has other functions such as anti-freeze materials, fossil fuels and solvents (Ballinger, P. \& Long, F.A., 1960). Ethanol is a flammable liquid and colorless and easily soluble in water, suitable as paint and perfume. It can also be used as an anti-septic (Arnett \& Venkatasubramaniam, 1983), which can kill the organism and prevent some of the viruses and bacteria. Given the properties of ethanol, then it can be stored for very long as an ingredient in alcoholic beverages

In the Quran, consumption of alcoholic beverages is prohibited because it can be harmful to humans. The Holy Quran says: "O ye who believe! Intoxicants and gambling, (dedication of) stones, and (divination by) arrows, are an abomination- of Satan's handiwork: eschew such (abomination), that ye may prosper" (Quran, 5:90). Modern studies have found effects of consumption of alcoholic beverages can cause harm to human life such as difficulty in walking, blurred vision and also the risk of the brain (Tortora \& Derrickson, 2012). Intake of alcohol at the time a person is in a state of hunger will cause him to forget what happened at that time, and this is known as an alcoholic blackout (Tracey \& Baume, 2000). Thus Islam forbids Muslims from drinking beer because it brings harm to the drinker and can lead to social problems. However in certain circumstances, such as in medicine, alcohol can be used with certain conditions (Press Release, Special Dialogue, the National Fatwa Council 14 to 16 July 2011). Among the conditions are such drugs are mixed with alcohol, which is used as a solvent and is not derived from the process of making wine.

\section{CONCLUSION}

Based on the discussion of examples in science contained in the physics and chemistry courses, clearly show that it has relevance either directly or indirectly with the verses of the Quran. This is a fraction of the examples that can be applied in Naqli science through the integration of science courses such as physics and chemistry at the basic level. Given Tamhidi Islamic Science University of Malaysia offers integrated science curriculum Naqli and aqli to its students, is necessary to periodically review the curriculum to improve the quality of the curriculum offered. In addition, the expert assessment is also indispensable to ensure the quality of the material and content provided is more relevant and accurate. 


\section{ACKNOWLEDGEMENT}

The author would like to acknowledge Research Management Centre, University Sains Islam Malaysia (USIM) for the management and financial support as this research was a part of its Grant (PPP/USG0115/FPQS/30/11415).

\section{REFERENCE LIST}

The Holy Quran

Abdul Maleque, Kh. (2013), Effects of Exothermic/Endothermic Chemical Reactions with Arrhenius Activation Energy on MHD Free Convection and Mass, Journal of Thermodynamics, V2013, doi.org/10.1155/2013/692516, Hindawi Publishing Corporation.

Abedin, A.H \& Rosen, M.A. (2011), A Critical Review of Thermochemical Energy Storage Systems, The Open Renewable Energy Journal, v4

Ahmad, M, Zanariah, C.W, Yusof, A \& Hanifah, S.A, (2011). Mengkagumi al-Quran Menerusi Penghayatan Kedinamikan Fenimina Alam Dari Perspektif Ilmu Kimia. Proceeding Seminar Wahyu Asas Tamadun 2011

Alcohol Advisory Council of New Zealanad (2012), Alcohol - the Body \& Health Effects A brief overview, Wellington: New Zealand

Ali, A.Y, (2002), The Meaning of the Holy Quran English-Arabic, Lahore: Bait ul Quran

Arnett, E.M. \& Venkatasubramaniam, K.G. (1983). "Thermochemical acidities in three superbase systems". J. Org. Chem. 48 (10): 1569

Aziz, A.A, Ibrahim, M.A, Shaker, M.H \& Noor, A.M (2016), Teaching Technique of Islamic Studies in Higher Learning Institutions for Non-Arabic Speakers: Experience of Faculty of Quranic and Sunnah Studies and Tamhidi Centre, Universiti Sains Islam Malaysia, Universal Journal of Educational Research 4(4): 755-760, Horizon Research Publishing, USA.

Ballinger, P. \& Long, F.A. (1960). "Acid Ionization Constants of Alcohols. II. Acidities of Some Substituted Methanols and Related Compounds1,2". Journal of the American Chemical Society 82 (4): 795

Cheshire, F. (2006) The Solar System and Beyond, Evans Brothers: London

Encyclopaedia Britannica, https://global.britannica.com/science/work-physics

Glenn Research Centre, National Aeronatics and Space Administration (2015), https://www.grc.nasa.gov/www/k-12/airplane/wteq.html

Haynes, W.M. (2013), Handbook of Chemistry and Physics, New York: Taylor \& Francis Group

Hyman, A.T (1993), "The Mathematical Relationship between Kepler's Laws and Newton's Laws". The American Mathematical Monthly, v100, n10. 932-936

Kazeroonian, A, Fr"ohlich, F, Raue, A, Theis, F.J, \& Hasenauer, J (2016), CERENA: ChEmical REaction Network Analyzer - A Toolbox for the Simulation and Analysis of Stochastic Chemical Kinetics, doi.org/10.1371/journal.pone.0146732

Kostic, M. (2004), Work, Power and Energy, Encyclopedia of Energy, v6, Elsevier.

Kox, A.J, Klein, M.J \& Schulmann R. (1997), The Foundation of the General Theory of Relativity, New Jersey: Princeton University Press

Ministry of Education Malaysia, Matriculation Colleges, http://www.moe.gov.my/my/direktori-kolej-matrikulasi

Ministry of Education Malaysia, Matriculation Division, http://www.moe.gov.my/my/program-matrikulasi

Ministry of Higher Education Malaysia, Department of Higher Education, http://upu.mohe.gov.my/web/\#.

Ministry of Higher Education Malaysia, Student Intake Management Division, https://online.mohe.gov.my/upu/emas/index_epanduan.php.

National Center for Biotechnology Information, "Ethanol - Compound Summary", https://pubchem.ncbi.nlm.nih.gov/compound/702 
National Institute on Deafness and Other Communication Disorders, USA, https://www.nidcd.nih.gov/health/balance-disorders.

Nermoen, A, Korsnes, R.I, Aursjø, O, Madland, M.V, Kjørslevik, T.A.C and Østensen, G. (2016), How Stress and Temperature Conditions Affect Rock-Fluid Chemistry and Mechanical Deformation, Frontiers in Physics, doi: 10.3389/fphy.2016.00002

Sabri, M.N.M, Aziz, A.A \& Ibrahim, M.A (2015), Sains Islam dan Pendidikan : Ke Arah Melahirkan Generasi Terbilang, Bangi : Darul Shakir

Selangor Matriculation College (Kolej Matrikulasi Selangor), http://www.kms.matrik.edu.my/index.php/component/content/article/88-program-matrikulasi/programyang-ditawarkan/80-program-yang-ditawarkan.

Tamhidi Centre, Course Outline (2014), Nilai: Universiti Sains Slalam Malaysia

Tamhidi Centre, Student Enrollment Report (2016), Nilai: Universiti Sains Islam Malysia

The Free High School Science Texts Authors (2005), A Textbook for High School Students Studying Physics, np

The National Fatwa Council, Press Release - Special Dialogue, 14 to 16 July 2011, http://www.efatwa.gov.my/sites/default/files/kenyataan_media_mengenai_alkohol_0.pdf

Tortora \& Derrickson,B.H. (2012). Essentials of Anatomy and Physiology. 9th International student edition. New York: Wiley

Tracey, D.J. \& Baume, B. (2000), Anatomica: The Complete Reference to the Human Body and How It Works. Australia: Random House

USNW, School of Physics, Sydney, Australia, http://www.animations. physics.unsw.edu.au/jw/work.htm\#work Verma, H.C. (2008), Concepts of Physics, New Delhi: Bharati Bhawan Publishers Distributors. 